\section{PRIIISIP KERJA SAMA DALAM TINDAK TUTUR}

[STUDI ETNOGRAFI KOMUNIKASI PADA POLISI

SENTRA PELAYANAN KEPOLISIAN TERPADU POLRES METRO DEPOK]

Manusia berkomunikasi dengan cara bertindak tutur. Namun, apakah tindak tutur yang diujarkan sudah sesuai dengan harapan antara penutur pada mitra tuturnya? Latar belakang penutur dan mitra tutur turut berperan dalam sebuah komunikasi. Penutur dan mitra tutur ingin terjalin komunikasi yang baik melalui tindak tutur, tetapi penutur dan mitra tutur melupakan sebuah prinsip yang sangat penting yaitu prinsip kerja sama. Tanpa prinsip kerja sama, tindak tutur tidak akan berjalan baik. Hasilnya, akan banyak kesalahpahaman yang dirasakan oleh penutur dan mitra tutur. Kesalahpahaman yang terus menerus terjadi dalam tindak tutur bisa menimbulkan sebuah image yang positif maupun negatif.

Melalui buku ini, pembaca bisa melihat tindak tutur yang terjadi antara penutur dengan mitra tutur secara nyata. Tindak tutur yang terdapat dalam buku ini merupakan gambaran nyata sebuah tindak tutur yang terjadi antara polisi dan masyarakat. Buku ini pun mengupas tindak tutur dan pematuhan prinsip kerja sama yang terjadi antara polisi dan masyarakat.

Buku ini membahas metode SPEAKING Dell-Hymes dalam membedah prinsip kerja sama yang terjadi antara penutur dan mitra tutur. Buku ini menyajikan cara menganalisis yang berbeda karena mengombinasikan metode SPEAKING dengan prinsip kerja sama dari tindak tutur polisi dan masyarakat.

Buku ini menggunakan bahasa yang mudah dipahami untuk mahasiswa, akademisi, polisi, dan masyarakat luas. Buku ini sangat tepat untuk dijadikan referensi bagi mahasiswa S1, S2, dan S3 serta akademisi yang ingin mendalami metode SPEAKING, prinsip kerja sama, dan tindak tutur.

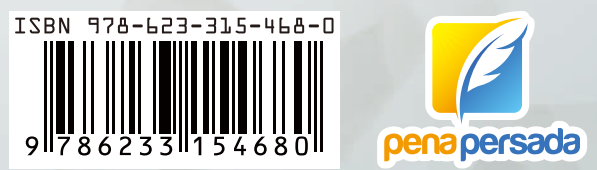

Ni Wayan Ayu Permata Sari

Prof. Dr. Zuriyati, M. Pd.

Prof. Dr. Yumna Rasyid, M. Pd.

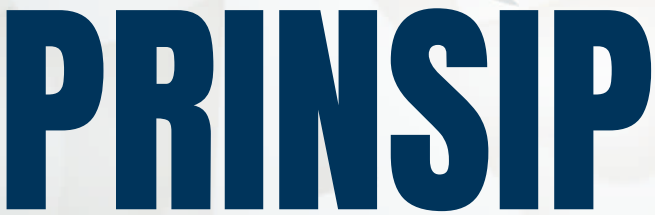

KERJA SAMA DALAM TIMDAK TUTUR [STUDI ETNOGRAFI KOMUNIKASI PADA POLISI SENTRA PELAYANAN KEPOLISIAN TERPADU POLRES METRO DEPOK] 


\section{PRINSIP KERJA SAMA DALAM TINDAK TUTUR}

(Studi Etnografi Komunikasi pada Polisi Sentra Pelayanan Kepolisian Terpadu Polres Metro Depok)

Ni Wayan Ayu Permata Sari

Prof. Dr. Zuriyati, M. Pd.

Prof. Dr. Yumna Rasyid, M. Pd.

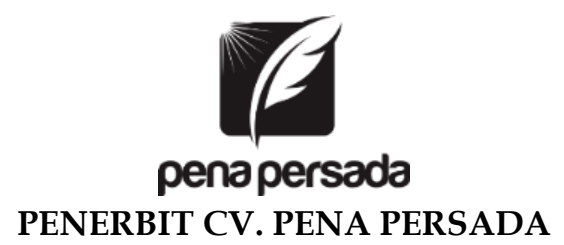




\title{
PRINSIP KERJA SAMA DALAM TINDAK TUTUR (Studi Etnografi Komunikasi pada Polisi Sentra Pelayanan Kepolisian Terpadu Polres Metro Depok)
}

\author{
Penulis: \\ Ni Wayan Ayu Permata Sari \\ Prof. Dr. Zuriyati, M. Pd. \\ Prof. Dr. Yumna Rasyid, M. Pd.
}

ISBN:

Editor:

Wiwit Kurniawan

Design Cover:

Retnani Nur Briliant

Layout:

Eka Safitry

\section{Penerbit CV. Pena Persada}

Redaksi:

Jl. Gerilya No. 292 Purwokerto Selatan, Kab. Banyumas

Jawa Tengah

Email: penerbit.penapersada@gmail.com

Website: penapersada.com Phone: (0281) 7771388

\section{Anggota IKAPI}

All right reserved

Cetakan pertama: 2021

Hak Cipta dilindungi oleh undang-undang. Dilarang memperbanyak karya tulis ini dalam bentuk apapun tanpa izin penerbit 


\section{KATA PENGANTAR}

Segala puji senantiasa kita panjatkan Kehadirat Tuhan Yang Maha Esa, atas segala Rahmat dan Karunia-Nya, akhirnya penulis dapat menyelesaikan penyusunan buku yang berjudul "PRINSIP KERJA SAMA DALAM TINDAK TUTUR (Studi Etnografi Komunikasi pada Polisi Sentra Pelayanan Kepolisian Terpadu Polres Metro Depok).“ Saya menyadari bahwa tanpa bantuan dan bimbingan dari berbagai pihak sangatlah sulit bagi saya untuk menyelesaikan karya ini. Oleh karena itu, saya mengucapkan banyak terima kasih pada semua pihak yang telah membantu penyusunan buku ini. Sehingga buku ini bisa hadir di hadapan pembaca.

Buku ini membahas tentang prinsip kerja sama yang dianalisis dengan menggunakan SPEAKING Hymes dari tindak tutur masyarakat dan polisi Sentra Pelayanan Kepolisian Terpadu (SPKT) Polres Metro Depok. Kajian dalam buku ini menunjukkan adanya fenomena unik dari tindak tutur Polisi SPKT dan masyarakat dalam pematuhan prinsip kerja sama Grice. Ditemukan bahwa pematuhan maksim kuantitas sebanyak 248 pasang tuturan, pematuhan maksim kualitas sebanyak 226 pasang tuturan, pematuhan maksim relevansi sebanyak 158 pasang tuturan, dan pematuhan maksim cara/pelaksanaan sebanyak 206 pasang tuturan. Kajian dalam buku ini menggunakan metode ethnografi komunikasi SPEAKING Hymes yang dianalisis dan dikaitkan dengan pematuhan maksim prinsip kerja sama Grice dalam tindak tutur polisi antara polisi dan masyarakat yang hadir di Sentra Pelayanan Kepolisian Terpadu (SPKT) Polres Metro Depok.

Penulis menyadari sepenuhnya dalam disertasi ini masih terdapat kekurangan ataupun kelemahan. Oleh karena itu, penulis mengharapkan kritik dan saran dari para pembaca untuk penyempurnaan disertasi ini. Penulis berharap, buku ini dapat memberikan motivasi untuk para pembaca dan berguna untuk kemajuan dan perkembangan ilmu pragmatik.

Penulis 


\section{DAFTAR ISI}

KATA PENGANTAR

DAFTAR ISI

BAB 1 PENDAHULUAN 1

A. Persoalan Tindak Tutur dalam Masyarakat 1

B. Fenomena Tindak Tutur di SPKT Polres Metro Depok 2

C. Analisis Penggunaan Maksim dalam Prinsip Kerja Sama Grice 5

D. Berbagai Kajian tentang Prinsip Kerja dan Tindak $\begin{array}{ll}\text { Tutur } & 12\end{array}$

BAB 2 KONSEP TINDAK TUTUR 16

A. Pengertian Tindak Tutur 16

B. Jenis-jenis Tindak Tutur 19

BAB 3 PRINSIP KERJA SAMA 28

A. Pengertian Prinsip Kerja Sama 28

B. Maksim Prinsip Kerja Sama 31

BAB 4 ETNOGRAFI KOMUNIKASI 33

BAB 5 MAKSIM PRINSIP KERJA SAMA GRICE DALAM TINDAK TUTUR POLISI 35

A. Maksim Kuantitas Prinsip Kerja Sama Grice dalam Tindak Tutur Polisi

B. Maksim Kualitas Prinsip Kerja Sama Grice dalam Tindak Tutur Polisi

C. Maksim Relevansi Prinsip Kerja Sama Grice dalam Tindak Tutur Polisi 50

D. Maksim Cara/Pelaksanaan Prinsip Kerja Sama Grice dalam Tindak Tutur Polisi 56

E. Analisis atas Prinsip Kerja Sama dalam Tindak Tutur Polisi 
BAB 6 KAJIAN ETNOGRAFI KOMUNIKASI ATAS MAKSIM PRINSIP KERJA SAMA GRICE DALAM TINDAK TUTUR POLISI

A. Rekapitulasi Maksim Prinsip Kerja Sama dalam Tindak Tutur Polisi SPKT Polres Metro Depok

B. Analisis Studi Etnografi Komunikasi atas Prinsip Kerja Sama dalam Tindak Tutur Polisi 69

BAB 7 PENUTUP $\quad 71$

DAFTAR PUSTAKA

$\begin{array}{ll}\text { Tentang Penulis } & 77\end{array}$ 


\section{PRINSIP KERJA SAMA DALAM TINDAK TUTUR}

(Studi Etnografi Komunikasi pada Polisi Sentra Pelayanan Kepolisian Terpadu Polres Metro Depok) 


\section{BAB 1 \\ PENDAHULUAN}

\section{A. Persoalan Tindak Tutur dalam Masyarakat}

Berawal dari tindak tutur, penutur dan mitra tutur bisa memahami apa yang diharapkan satu sama lain. Idealnya, suatu pertuturan hendaknya bisa membuat hubungan sosial yang lebih erat karena saling berinteraksi. Namun, realita yang terjadi di masyarakat justru sebaliknya. Tindak tutur bisa menjadi bumerang bagi penutur dan mitra tutur itu sendiri dan berakibat salah paham satu dengan yang lainnya.

Hal tersebut terjadi karena adanya kekurangpahaman penutur dan mitra tutur tentang hadirnya konteks dalam suatu pertuturan. Pendapat ini didukung oleh Leech \& Neil (1993) yang menyatakan bahwa dalam pragmatik yang paling utama dan penting adalah memiliki konteks dan pemahaman yang sama antara penutur dan mitra tutur. Hal ini sangatlah penting untuk memahami tuturan atau percakapan.

Diperkuat lagi oleh Moldovan bahwa "Anggapan dan konteks adalah aturan yang paling penting dalam tindak tutur" (Moldovan, 2016). Terlepas nantinya, konteks yang terbangun dalam sebuah tindak tutur meliputi satu bidang tertentu-hukum atau bidang lainnya-atau tidak, dalam bertindak tutur hendaknya tetaplah Kamus Besar Bahasa Indonesia (KBBI) dan Pedoman Umum Ejaan Bahasa Indonesia (PUEBI) dijadikan pijakan akan tercipta pemahaman yang sama, artinya penutur dan mitra tutur hendaknya menggunakan bahasa Indonesia yang baik dan benar ketika melakukan tindak tutur. 


\section{B. Fenomena Tindak Tutur di SPKT Polres Metro Depok}

Di segala bidang akan banyak fenomena tindak tutur antara penutur dan mitra tutur. Pada buku ini, tindak tutur yang akan dikaji mengarah pada tindak tutur antara Polisi dan Masyarakat. Masyarakat yang dimaksud adalah masyarakat yang hadir ke Sentra Pelayanan Kepolisian Terpadu (SPKT) Polres Metro Depok dalam rangka melaporkan segala hal yang menjadi tugas dari SPKT, seperti laporan kehilangan dokumen-dokumen berharga seperti KTP, SIM, BPKB, STNK, buku tabungan, kartu ATM, hingga surat tanah; pencurian, tindak kekerasan, hingga pencemaran nama baik. Tentunya ranah SPKT sebagai gerbang dari segala laporan. Dari SPKT inilah laporan yang disampaikan oleh masyarakat akan ditindaklanjuti pada bagian-bagian lain yang terdapat di Polres Metro Depok, seperti unit Jatanras, Krimsus, Narkoba, atau PPA. Melihat tugas Polisi SPKT yang begitu penting karena setiap harinya akan selalu kedatangan masyarakat yang ingin melaporkan sesuatu, menjadi inspirasi untuk melakukan kajian di SPKT Polrestro Depok.

Kajian ini akan melihat fenomena prinsip kerja sama dalam tindak tutur dengan latar belakang yang berbeda yang terjadi di Polres Metro Depok, khususnya di SPKT. Setiap harinya polisi selalu berkomunikasi dengan masyarakat yang sedang menghadapi masalah sehingga perlu melaporkan kasusnya tersebut ke SPKT. Adapun polisi yang bertugas di SPKT Polres Metro Depok terbagi atas tiga shift yang beranggotakan lima polisi dengan berbagai tingkat jabatannya. Polisi tersebut berdinas dengan istilah 12-24. Shift pertama dimulai pukul 08.00 WIB hingga $20.00 \mathrm{WIB}$; shift kedua dimulai pukul 20.00 WIB; dan shift ketiga libur selama 24 jam (1 hari).

Polisi SPKT akan memberikan solusi dari segala permasalahan yang sedang dihadapi masyarakat yang telah melaporkan masalahnya ke bagian SPKT dengan tindak tutur yang berbeda meskipun tujuannya sama, yakni solusi terbaik 
untuk masyarakat. Perbedaan tindak tutur yang dimaksud adalah bahasa yang berisikan kata-kata yang diujarkan oleh polisi dan masyarakat yang memiliki latar belakang yang berbeda. Fenomena yang terjadi di SPKT Polres Metro Depok sehingga terpilih menjadi latar kajian dalam buku ini karena Masyarakat pernah kecewa dengan tindak tutur dengan oknum Polisi SPKT saat melaporkan kasus yang telah dihadapi. Hal tersebut merupakan rekam jejak yang tidak baik tentunya. Penulis menduga bahwa Polisi belum menjalankan SOP dengan baik, padahal SOP yang ada sangatlah tepat untuk dijalankan dan akan memberi tanggapan positif dari Masyarakat.

Polres Metro Depok selalu berupaya memberikan pelayanan terbaik guna melayani masyarakatnya. Hal ini tergambar dari peluncuran aplikasi Halo Polisi dan Panic Button yang dirilis pada tahun 2018 lalu. Dilansir dalam laman Polrestadepok.blogspot.com, kedua aplikasi tersebut adalah salah satu bentuk pelayanan kepolisian berbasis IT untuk meningkatkan kecepatan pelayanan kepada masyarakat. Lebih lanjut, kedua aplikasi tersebut bisa didapatkan oleh masyarakat dengan cara mengunduh melalui Google Play Store.

Masih dari laman resmi Polres Metro Depok, terdapat standar pelayanan yang ditetapkan pada SPKT Polrestro Depok. Melalui moto "Karena kepuasan Anda adalah tujuan kami", SPKT Polrestro Depok ingin memberikan pelayanan yang maksimal kepada masyarakat. Oleh karena itu, SPKT Polrestro Depok menetapkan standar pelayanan sehingga dapat menjadi tolok ukur dalam menyelenggarakan pelayanan dan acuan penilaian kualitas terhadap SPKT Polrestro Depok. Selain itu, standar pelayanan juga sebagai kewajiban dan janji kepada masyarakat dalam rangka pelayanan yang berkualitas, cepat, mudah, terjangkau, dan terukur. 
Komponen standar pelayanan, sebagaimana diatur dalam Undang-undang Nomor 25 Tahun 2009, peraturan dibedakan menjadi dua bagian, yang dipaparkan berikut ini.

1. Komponen standar pelayanan yang terkait dengan proses penyampaian pelayanan (Service Delivery), meliputi:
a. persyaratan;
b. sistem, mekanisme, dan prosedur;
c. jangka waktu pelayanan;
d. biaya/tarif;
e. produk pelayanan;
f. penanganan pengaduan, saran, dan masukan.

2. Komponen standar pelayanan yang terkait dengan proses pengelolaan pelayanan di internal organisasi (Manufacturing), meliputi:
a. dasar hukum;
b. sarana dan prasarana, dan/atau fasilitas;
c. kompetensi pelaksana;
d. pengawasan internal;
e. jumlah pelaksana;
f. jumlah pelayanan;
g. jaminan keamanan dan keselamatan pelayanan;
h. evaluasi kinerja pelaksana.

Berbagai upaya sudah dilakukan oleh SPKT Polrestro Depok untuk menjadi SPKT terbaik bagi masyarakatnya. SPKT Polrestro Depok tampaknya sudah mengubah dan memperbaiki diri dari berbagai permasalahan mengenai ketidakpuasan pelayanan yang dihadapinya sebelum tahun 2018 lalu-peluncuran aplikasi Halo Polisi dan Panic Button. Adapun kasus yang Penulis maksudkan ialah adanya laporan dua orang yang tidak puas dengan perlakuan oknum dari anggota SPKT Depok. Hal ini dilansir dari Kompas.com tahun 2015, dengan judul berita Warga merasa tak direspons saat laporkan penipuan. Dua warga datang ke SPKT Polrestro Depok karena merasa ditipu oleh situs jual beli daring. Namun, hal tidak positif didapatkan dari dua warga ini karena oknum polisi SPKT menyatakan bahwa agar pelapor 
baiknya mengikhlaskan dan membandingkan kasusnya dengan kasus yang lebih besar. Akibat tindak tutur oknum tersebut, warga ini mengaku kecewa dan hingga akhirnya terungkap ke media. Dampak fatalnya lagi ialah dua warga tersebut merasa terhina atas tindak tutur dari oknum polisi tersebut. Kasus ini menegaskan bahwa tindak tutur bisa menjadi teman sekaligus lawan bagi penutur apabila tidak memperhatikan prinsip-prinsip yang terdapat dalam percakapan, khususnya prinsip kerja sama.

\section{Analisis Penggunaan Maksim dalam Prinsip Kerja Sama Grice}

Prinsip kerja sama dalam kajian ini akan berfokus pada penggunaan empat maksim dalam prinsip kerja sama Grice (1975). Adapun maksim yang dimaksudkan adalah maksim kuantitas, kualitas, relevansi, dan cara/pelaksanaan. Maksim inilah yang menjadi salah satu indikator apakah tindak tutur antara Polisi dan Masyarakat di SPKT Polrestro Depok sudah berjalan baik atau belum. Selain itu, aspek dari tempat, partisipan, tujuan, instrument, norma, dan genre pun dijadikan indikator tindak tutur polisi dan masyarakat. Jika berjalan baik, artinya berkurangnya penilaian negatif pada Polisi SPKT Polrestro Depok di mata masyarakat. Penilaian nantinya diambil dari kuesioner dan wawancara singkat pada masyarakat yang telah hadir memberikan laporan pada SPKT Polrestro Depok.

Kasus lain yang sempat mencoreng wajah SPKT Polres Depok adalah ketidakjelasan selama 2 tahun dalam penanganan laporan warga terhadap kasus penipuan yang dialaminya. Seperti apa yang dilansir dari Nusantaranews86.com (2019) mengungkapkan bahwa:

“Berdasarkan Surat Tanda Penerimaan Laporan/Pengaduan Nomor: STPLP/631/K/III/2017/PMJ/Resta Depok, Sabtu tanggal 4 Maret 2017, Juliana melaporkan kasus penipuan yang dialaminya ke Polresta Depok melalui Ka SPKT- Kanit 3 SPKT 
yang ditandatangani Iptu Suprihatin, bahwa dirinya telah menjadi korban kasus penipuan (Pasal 378 KUHP) yang terjadi pada 23 Maret 2015 lalu. ... Selama kurun waktu dua tahun proses, korban merasa pihak Penyidik Kepolisian tak serius menangani kasus tersebut."

Kasus ini menambah jejak ketidakpuasan warga kepada SPKT Polres Depok.

Selain itu, berdasarkan hasil evaluasi pelayanan publik yang rilis pada tanggal 15 Januari 2019 dalam laman resmi Mempan.go.id, yang dilakukan Kementerian Pendayagunaan Aparatur Negara dan Reformasi Birokrasi (PANRB) terhadap 13 Polres di lingkungan Polda Metro Jaya, Polrestro Depok mendapatkan nilai B- 'baik dengan catatan'. Evaluasi pelayanan publik pada Polres dan Polresta dilingkup Polda Metro Jaya ini merupakan upaya mengetahui kinerja unit-unit pelayanan serta melakukan pemantauan dan evaluasi kinerja penyelenggara pelayanan publik, dalam hal ini Polda Metro Jaya. Ada tiga fokus evaluasi pelayanan publik, yaitu pelayanan Surat Izin Mengemudi (SIM), pelayanan Surat Keterangan Catatan Kepolisian (SKCK), dan pelayanan Sentra Pelayanan Kepolisian Terpadu (SPKT).

Nilai B- yang diberikan kepada Polres Depok memiliki arti 'baik dengan catatan'. Istilah dengan catatan inilah yang membuat Penulis lebih tertarik lagi untuk melakukan kajian di Polres Depok, khususnya SPKT. Penulis ingin mengetahui lebih jauh lagi tentang catatan apa yang dimaksudkan-yang berkaitan dengan tindak tutur. Atas dasar kajian Menpan kepada Polres Depok dan salah satu fokus kajian ialah SPKT inilah, penulis merasa sangatlah tepat jika kajian ini menggunakan metode kajian etnografi komunikasi (ethnography of communication).

Lebih lanjut dikatakan, hasil dari evaluasi pelayanan publik tersebut diharapkan dapat mendorong kinerja Kepolisian Resor untuk memberikan pelayanan yang prima kepada masyarakat. Tujuan lainnya adalah untuk mengembalikan dan menjaga kepercayaan publik atas kinerja 
aparat kepolisian dalam memberikan pelayanan terbaik bagi masyarakat. Lebih dari itu, perlu diperhatikan pengintegrasian sistem teknologi informasi (TI) pada pelayanan SPKT dengan unit terkait lainnya untuk penyelesaian tindak lanjut laporan. (Menpan.go.id).

Berdasarkan data di atas, dapat terlihat bahwa SPKT memiliki peranan yang sangat penting bagi citra diri dalam tubuh kepolisian. Hal ini tidak dapat disangkal karena SPKT merupakan salah satu dari tiga fokus penilaian mengenai kepuasan publik yang dilakukan oleh Menpan dan hasil evaluasi tersebut berimbas pada citra diri dari masyarakat terhadap kepolisian. Semakin baik pelayanan yang dilakukan oleh kepolisian, khususnya SPKT, semakin baik pula citra diri kepolisian di mata masyarakat. Bentuk pelayanan yang bisa diterapkan oleh polisi SPKT dimulai dari sebuah tindak tutur yang diawali dalam SOP oleh polisi kepada masyarakat yang hadir di SPKT Polrestro Depok.

Penulis melihat adanya budaya tindak tutur yang kurang baik serta prinsip kerja sama yang belum terlaksana dalam pelaksanaan SOP di SPKT sehingga terjadi ketidakpuasan dalam penanganan kasus. Hal ini terbukti dari penjelasan penulis di atas yang bersumber dari laman Nusantaranews86.com dan Kompas.com. Penulis pun mendapatkan informasi dari laman Menpan.go.id yang menguatkan temuan dari kedua laman tersebut dengan penilaian yang diberikan Mempan kepada Polres Depok. Mempan memberikan penilaian B- dengan keterangan 'baik dengan catatan' dengan salah satu penilaiannya yaitu pelayanan yang terdapat dalam SPKT di Polrestro Depok.

Temuan yang didapatkan penulis mengenai Sentra Pelayanan Kepolisian Terpadu (SPKT) yang dimiliki oleh Polrestro Depok-kelebihan dan kekurangannya-menjadi latar belakang terpilihnya SPKT Polres Metro Depok menjadi tempat kajian. Adapun metode yang digunakan adalah metode ethnography of communication dengan menggunakan teori SPEAKING Dell-Hymes. 
Jadi, prinsip kerja sama dibutuhkan penutur untuk menggunakan bahasa dalam tindak tutur secara tepat untuk menjalin kerja sama kepada mitra tutur. Penerapan prinsip kerja sama dalam tindak tutur perlu memerhatikan empat maksim. Empat maksim yang dimaksud adalah maksim kuantitas, kualitas, relevansi, dan pelaksanaan. Empat maksim tersebut digunakan untuk membantu penutur dan mitra tutur agar lebih teratur, tertata, dan terstruktur dalam berkomunikasi sehingga dapat terjalin kerja sama yang baik sehingga pesan pun dapat tersampaikan dengan baik.

Kajian mengenai prinsip kerja sama dalam tindak tutur sangatlah menarik terutama ditinjau dari komunikasi masyarakat daerah tertentu-dalam hal ini kajian etnografi komunikasi. Tentu pendapat tersebut beralasan karena tiap masyarakat daerah tertentu akan menggunakan bahasa dan kebiasaan tertentu dalam berkomunikasi sehingga hasilnya nanti akan menambah khazanah tentang bahasa dan penggunaannya dalam bidang kebahasaan. Tidak hanya itu, kajian ini berfokus pada latar kajian yakni di SPKT Polres Metro Depok, tentunya kajian ini akan bermanfaat juga bagi anggota kepolisian secara umum, khususnya anggota SPKT di Polres Metro Depok.

Pentingnya kajian mengenai prinsip kerja sama dan tindak tutur dalam masyarakat tergambar dari beberapa penelitian terdahulu. Pertama, hasil penelitian dari Aminah (2017) dalam judul Prinsip Kerja Sama dan Kesantunan Bahasa dalam Wacana Chatting antara Mahasiswa dan Dosen Jurusan Bahasa Indonesia Melalui Smartphone (Kajian Sosiopragmatik) menunjukkan bahwa terjadi bentuk-bentuk ketidaksambungan antara penutur dan petutur tersebut terutama terdapat dalam maksim relevansi, adanya wujud pematuhan prinsip kerja sama kesantunan bahasa mahasiswa dalam chatting di whatsapp dan sms melalui smartphone didasarkan pada terpenuhinya ketentuan maksim-maksim yang ada prinsip kesantunan Leech dan Grice (maksim kebijaksanaan, maksim kedermawanan, maksim 
penghargaan, maksim permufakatan, maksim kesederhanaan, maksim kesimpatisan, maksim kuantitas, maksim kualitas, maksim relevansi, dan maksim pelaksanaan) (Aminah, 2017).

Penelitian kedua adalah penelitian Mulya Tiara Fauziah, Emzir, dan Ninuk Lustyantie (2018) dalam Judul Pelanggaran Prinsip Kerja Sama dalam Tuturan Diskusi Kelas Bahasa Indonesia. Hasil dari penelitian ini adalah tuturantuturan dalam diskusi kelas bahasa Indonesia yang melanggar prinsip kerja sama ini menjadikan tidak terjalinnya komunikasi yang baik sehingga diskusi yang terjadi kurang efektif. Hal ini dipicu karena beberapa hal seperti adanya rasa kurang percaya diri dari penutur atau lawan tutur, ingin menunjukkan kelucuan yang membuat suasana diskusi menjadi tidak monoton, kurang paham dan tidak tuntasnya di dalam memberikan tanggapan saat berdiskusi (Fauziah et al., 2018).

Penelitian ketiga adalah penelitian Ni Wayan Pasek Lestari, I Nyoman Sudiana, I Wayan Artika (2019) dalam Judul Prinsip Kerja Sama dalam Novel Magening Karya Wayan Jengki Sunarta. Hasil penelitian ini adalah novel Magening Karya Wayan Jengki Sunarta ditemukan semua bentuk maksim prinsip kerja sama dengan rincian 76 tuturan yang mengandung prinsip kerja sama, yang meliputi 6 bentuk kerja sama pada maksim pelaksanaan, 21 bentuk kerja sama pada maksim kualitas, 37 bentuk kerja sama pada maksim relevansi, dan 12 bentuk kerja sama pada maksim kuantitas. Sedangkan pelanggaran bentuk PKS dalam novel Magening ditemukan 35 tuturan yang melanggar maksim PKS. Dengan rincian 6 bentuk tuturan pelanggaran pada maksim pelaksanaan, 5 bentuk tuturan pelanggaran pada maksim kualitas, 6 bentuk tuturan pelanggaran pada maksim relevansi, dan 9 bentuk tuturan pada maksim kuantitas (Lestari et al., 2019)

Penelitian keempat adalah penelitian Andoyo Sastromiharjo dan Dian Anggraini Febtiani (2019) dalam judul The Realization of the Principles of Conversation in the Teachers 
and Students" Speech in Indonesian Classroom Interaction. Hasil penelitian ini adalah melalui realisasi prinsip-prinsip percakapan dalam interaksi kelas, dapat disimpulkan bahwa kualitas komunikasi edukatif mempengaruhi pencapaian tujuan pembelajaran (Sastromiharjo \& Febtiani, 2020).

Penelitian kelima adalah penelitian Dian Wahyunianto, Djatmika, dan Dwi Purnanto (2020) dalam judul Grice's Cooperative Principles Violation in the Communication of Children with Autism. Penelitian ini bertujuan untuk menunjukkan bagaimana anak-anak dengan autisme melanggar prinsipprinsip kerja sama Grice dan apa yang menyebabkannya. Hasil penelitian ini adalah Metode analisis pragmatis heuristik Leech digunakan untuk menganalisis data. Hasil penelitian menunjukkan bahwa 67,65\% ucapan yang diucapkan oleh anak-anak dengan autisme melanggar 1 pepatah, 20,59\% ucapan melanggar 2 maksim dan 3 maksim pelanggaran ditemukan pada 2,94\% ucapan. 4 pelanggaran maksim juga ditemukan yang menunjukkan bahwa ada $8,82 \%$ ucapan anak-anak dengan autisme gagal memenuhi prinsip kerja sama. Masalah bahasa dan pembangunan sosial dianggap bertanggung jawab atas pelanggaran serta ketidakmampuan mereka untuk tetap fokus dianggap sebagai penyebab maksim relevansi menjadi maksim yang paling dilanggar dalam penelitian ini (Wahyunianto et al., 2020).

Penelitian keenam adalah penelitian Hilman Pardede dan Herman dalam judul A Study of Speech Act Between Seller and Buyers in 'Sinaga Shop'. Penelitian ini bertujuan untuk mengetahui tindak tutur antara penjual dan pembeli di 'Toko Sinaga Jalan Melanthon Siregar Pematangsiantar. Tindak tutur terkait dengan ujaran. para peneliti menemukan bahwa ada beberapa kata kerja yang digunakan oleh penjual dan pembeli dalam percakapan transaksional harian mereka, yaitu: Perwakilan termasuk menyarankan, melaporkan, menyatakan, menginformasikan, mengeluh. Petunjuk termasuk bertanya, meminta, memesan. Ekspresif termasuk meminta maaf, terima kasih, maaf. Termasuk di dalamnya adalah penawaran dan Deklaratif mencakup hukuman (Pardede \& Herman, 2020). 
Penelitian ketujuh adalah penelitian Qorinta Shinta dalam judul Pemerolehan Pragmatik dalam Bahasa Anak Studi Kasus Prinsip Kerja Sama - Maksim Grice pada Anak Usia Enam (6) Tahun. Penelitian ini bertujuan untuk menggambarkan sejauh mana prinsip kerja sama maksim Grice mempengaruhi seorang anak dalam interaksi/menjawab pertanyaannya, maksim apa yang dilanggar dan faktor-faktor apa yang mungkin menyebabkan hal itu. Data menunjukkan bahwa seorang anak berusia enam tahun cukup sadar untuk tidak melanggar maksim Grice (kuantitas, kualitas, relevansi, cara) dengan memberikan jawaban langsung. Pelanggaran terhadap maksim kualitas, kuantitas, dan relevan yang terjadi menunjukkan bahwa ia hanya memiliki sedikit pengetahuan tentang topik tersebut (Shinta, 2010).

Berdasarkan latar belakang masalah yang telah dipaparkan peneliti, maka fokus kajian ini adalah "Prinsip kerja sama dalam tindak tutur Polisi unit Sentra Pelayanan Kepolisian Terpadu (SPKT) Polres Metro Depok dan masyarakat dianalisis dengan etnografi komunikasi". Adapun subfokus dalam kajian ini adalah. 1) aksim kuantitas prinsip kerja sama dalam tindak tutur polisi unit Sentra Pelayanan Kepolisian Terpadu (SPKT) Polres Metro Depok dan masyarakat dianalisis dengan etnografi komunikasi. 2) Maksim kualitas prinsip kerja sama dalam tindak tutur polisi unit Sentra Pelayanan Kepolisian Terpadu (SPKT) Polres Metro Depok dan masyarakat dianalisis dengan etnografi komunikasi. 3) Maksim relevansi prinsip kerja sama dalam tindak tutur polisi unit Sentra Pelayanan Kepolisian Terpadu (SPKT) Polres Metro Depok dan masyarakat dianalisis dengan etnografi komunikasi.4) Maksim cara/pelaksanaan prinsip kerja sama dalam tindak tutur polisi unit Sentra Pelayanan Kepolisian Terpadu (SPKT) Polres Metro Depok dan masyarakat dianalisis dengan etnografi komunikasi.

Hasil kajian ini diharapkan dapat memberikan kontribusi yang signifikan pada kemajuan dan perkembangan dunia kajian, pendidikan, serta pengajaran bahasa, khususnya 
pengajaran bahasa Indonesia. Hal ini berkaitan dengan adanya teori tindak tutur atau speech act basic theory yang sangat penting untuk diterapkan di ranah penelitian yang relevan dan dalam kehidupan sosial masyarakat penutur.

Selain itu, kajian ini dilakukan dalam konteks pragmatik yang digunakan dalam pengajaran bahasa, khususnya bahasa Indonesia dengan metode etnografi komunikasi yang berakar dari ilmu antropologi dan sosiologi. Oleh sebab itu, hasil kajian ini diharapkan bermanfaat bagi kegiatan praktis pengajaran bahasa Indonesia, khususnya dalam prinsip kerja sama dalam tindak tutur, serta bidang antropologi dan sosiologi serta kepolisian.

Diharapkan, hasil kajian dalam buku ini dapat menjadi rujukan atau referensi dalam kegiatan belajar mengajar (KBM) dan penelitian bahasa. Selanjutnya, buku ini diharapkan juga menjadi referensi bagi peneliti lain, terkait pengembangan teori prinsip kerja dan tindak tutur serta bagi peneliti lain yang berminat meneliti bidang yang relevan. Di bidang kepolisian, hasil kajian ini diharapkan menjadi SOP terbaru dalam bertindak tutur oleh Polisi SPKT di Polres Metro Depok khususnya, Polri umumnya.

\section{Berbagai Kajian tentang Prinsip Kerja dan Tindak Tutur}

Berikut ini dikemukakan beberapa hasil penelitian yang relevan dengan kajian dalam buku ini. Pertama, penelitian yang dilakukan oleh Zhou (2009) yang berjudul Cooperative Principle in Oral English Teaching. Penelitian bertujuan untuk menyelidiki prinsip kerja sama dalam pengajaran Bahasa Inggris di Sekolah Tinggi.

Perbedaan penelitian yang telah dilakukan oleh Mai Zhou dengan kajian yang peneliti lakukan terletak pada fokus penelitiannya. Penelitian tersebut berfokus pada dasar bahasa yang terlibat dalam proses pengajaran bahasa Inggris. Sedangkan, dalam buku ini berfokus pada prinsip kerja sama dalam tindak tutur Polisi dan Masyarakat yang hadir di SPKT di Polrestro Depok. 
Penelitian kedua adalah penelitian yang dilakukan oleh Shams dan Afghari (2011) yang berjudul Effects of Culture and Gender in Comprehension of Speech Acts of Indirect Request. Penelitian bertujuan untuk menyelidiki tindak tutur permintaan tidak langsung yang digunakan oleh orang Iran dalam komunikasi sehari-hari. Perbedaan penelitian yang telah dilakukan oleh Rabe'a Shams dan Akbar Afghari dengan kajian di buku ini terletak pada fokus penelitiannya. Penelitian tersebut berfokus hanya pada tindak tutur yang digunakan oleh orang Iran dalam kehidupan sehari-hari. Sedangkan, kajian di buku ini berfokus pada prinsip kerja sama dalam tindak tutur Polisi dan Masyarakat yang hadir di SPKT di Polrestro Depok.

Penelitian ketiga adalah penelitian yang dilakukan oleh Rohaniyah (2013) yang berjudul Socio-Pragmatic Study; The Obscurity of Gricean Maxims (Cooperative Principle Rules) [The Study of Flouted Maxims in Conversation Through Gender Categories]. Penelitian bertujuan untuk menyelidiki pelanggaran empat maksim dalam prinsip kerja sama yang terfokus pada gender.

Perbedaan penelitian yang telah dilakukan oleh Jaftiyatur Rohaniyah dengan buku ini terletak pada fokus penelitiannya. Penelitian tersebut berfokus pada pelanggaran empat maksim dalam prinsip kerja sama yang terfokus pada gender. Sedangkan, dalam kajian di buku ini berfokus pada prinsip kerja sama dalam tindak tutur Polisi dan Masyarakat yang hadir di SPKT di Polrestro Depok.

Penelitian keempat adalah penelitian yang dilakukan oleh Akinwotu (2013) yang berjudul A Speech Act Analysis of the Acceptance of Nomination Speeches of Chief Obafemi Awolowo and Chief M.K.O. Abiola. Penelitian bertujuan untuk menyelidiki peran bahasa dalam komunikasi dan interpretasi niat dengan memeriksa pidato politik yang dipilih sebagai bagian dari wacana dengan tujuan tertentu. 